\title{
Modern Increasing Environmental Problems of Atmosphere Pollution Leading to Significant Increase in Planet Population Deaths and Economic Damage to Global Economy
}

Vadim Azarov ${ }^{\prime}$; Vadim Kutenev ${ }^{2}$

${ }^{1}$ Lead Economist, Candidate of Engineering Science, PJSC TATNEFT;

Build. 1, 17, Tverskoy Boulevard, Moscow 103104, Russia;

${ }^{2}$ Expert Council Chairman, Doctor of Engineering Science,

Honored Worker of Science of the Russian Federation;

FSUE "NAMI", Russia, Moscow,

2 Avtomotornaya St., 125438

Abstract. The article analyzes two existing social, technical and economic problems which the world community shall focus on and pay special attention to.

Key words: Atmosphere pollution, atmosphere contamination, hazardous substances, particulate matters, cancerogenic substances, automotive vehicles

During 2020-2021, the population of our planet has been frightened due to more than 5.0 million people deaths because of the COVID-19 pandemic as of 01 December 2021. However currently, according to the research by the World Health Organization (WHO), information is provided on elevated concentrations of particulate matters (PM) in the air by regions and continents of our planet within the controlled period of 2008-2013. More than 7 million people die annually in silence due to excessively increasing coal and oil consumption by industry and transport operations (Figure 1) [1,2].

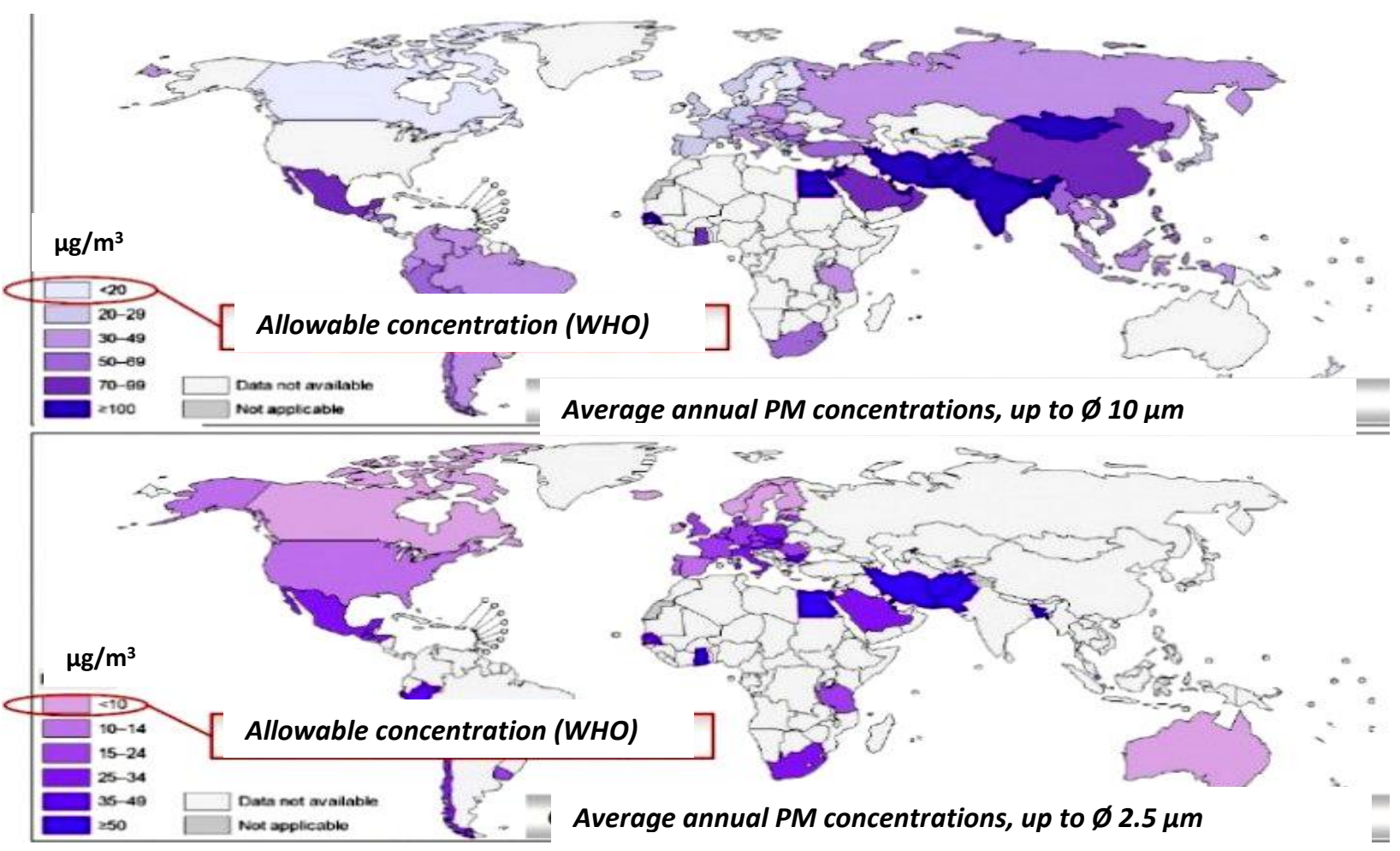

Fig. 1. Average annual concentrations of PM from 0 to 2.5 and up to $10 \mu \mathrm{m}$ in the atmosphere of our planet. 
The WHO states especially that due to this reason more than 7 million people die each year being in such polluted atmosphere containing particulate matters (PM) able to penetrate deep inside the lungs and cardiovascular system, causing lung cancer, stroke, cardiovascular diseases and pneumonia [1,2].

The new modern problem of atmospheric pollution in large cities revealed by the Russian studies is not discussed as widely as this much-discussed in the press and on television pandemic of different virus strains having a psychologically terrifying influence on the planet population by an expanding danger.

Figure 2 shows the averaged summary results of the Russian research on comparative actual ratio and forecast for change of hazardous PM emissions within the period from 2000 to 2030 caused by other vehicle systems (brake systems, tyres) and by asphalt roadway wear against the regulatory requirements of UN Regulations on PM emissions in EG through the example of the growth of the Russian vehicle fleet $[3,4,5,6]$.

Based on the materials of the comprehensive research performed in the Russian Federation (Figure 2), a summary conclusion has been made that today for 2020 we can state the following percentage rate of emissions of especially hazardous PM from $2.5 \mu \mathrm{m}$ to $10 \mu \mathrm{m}$ : in urban or city conditions with $\mathrm{EG}-12 \%$; from braking systems $-1.5 \%$; from tyres $-5 \%$ and from asphalt roadway $-81.5 \%$.

Despite such science and industry achievements in reduction of PM emissions in exhaust gases (EG), WHO experts did not pay due attention to particulate matter emissions of non-exhaust origin emitted by vehicles during operation due to the wear of tyres and especially of asphalt roadway $[3,4,5,6]$. 


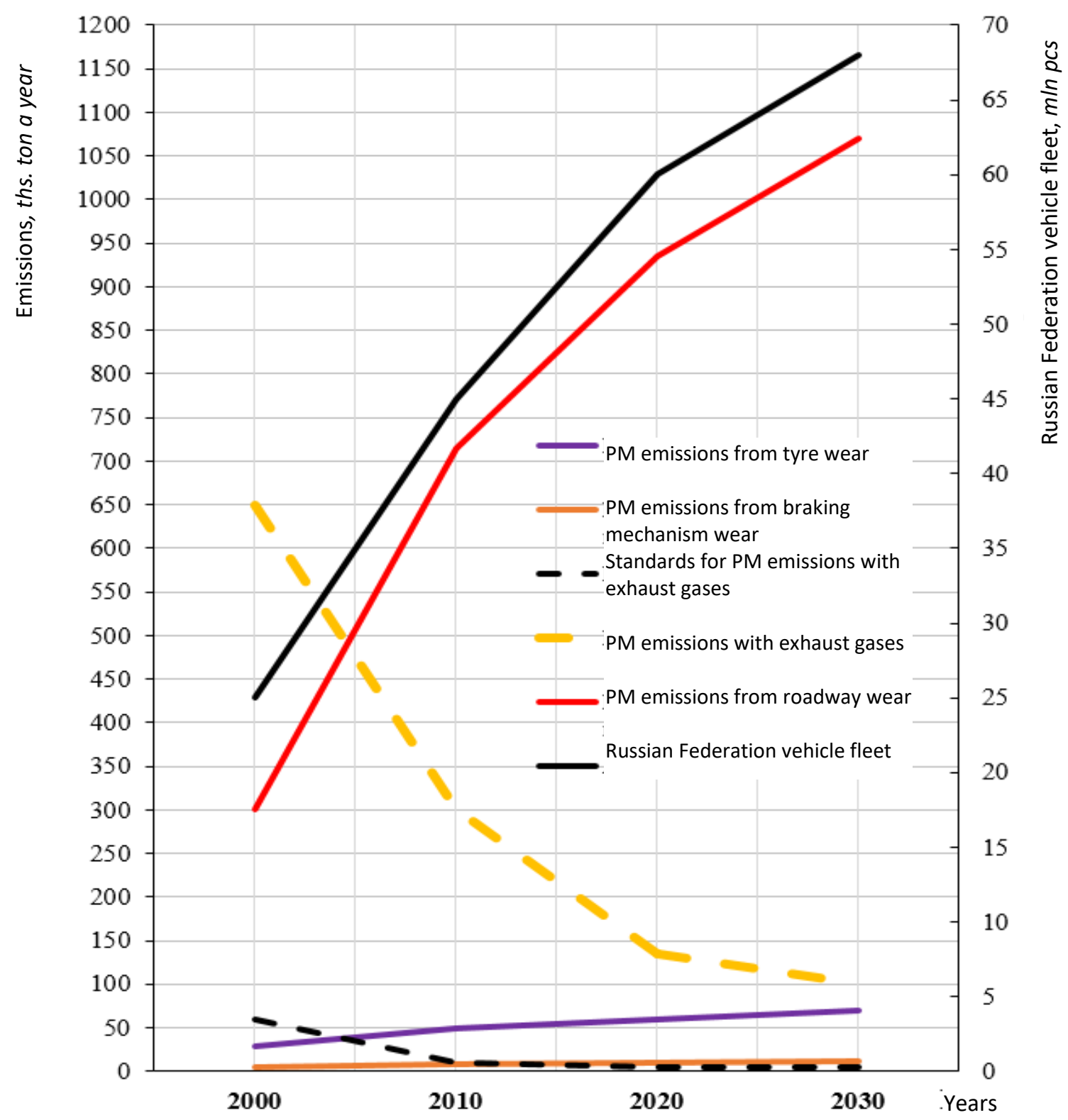

Fig. 2. Dynamics and forecast of annual PM emissions from wear of tyres, braking mechanisms and asphalt roadway in the Russian Federation, in tons, compared to the emissions of and emissions limits (UN standards) for PM in EG.

In addition to the WHO research [1,2] on global air pollution of our planet, research was performed by FSUE "NAMI" in 2012-2014 on definition of the number of hazardous particle matters in the air over the traffic way, in order to determine their influence on drivers and passengers in vehicle passenger compartments under real-life operation conditions, as well as measurements of particulate matters content both in outside air and in vehicle passenger compartment during driving in heavy urban traffic (Figure 3) [7]. 


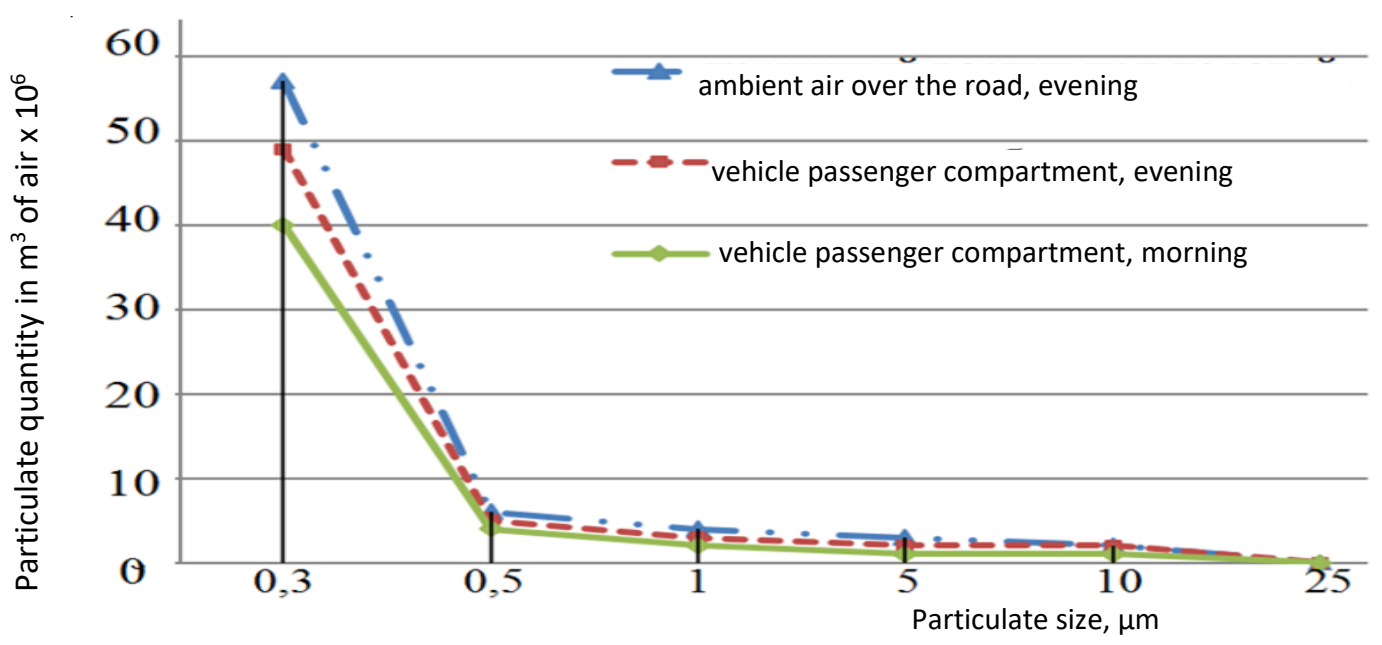

Fig. 3. Content of particulate matters in the outside air and in the vehicle passenger compartment during urban driving (in heavy traffic).

Thus, the filters currently applied to clean the air coming to the passenger compartment are not sufficiently effective and require significant improvement, especially in terms of very small, less than 1 micron, PM.

Due to the abovementioned varying assessment of air pollution by state and international organizations, in particular in large cities only by exhaust gases, there has risen a global energy and environmental conflict between the transport, the society and the environment which by the current time period has become critical and violently aggravating against an intensive search for the solutions to this ecological problem only through electric vehicles (EV) and alternative fuels, including hydrogen, for development of which large economic resources are being expended.

However, at the same time, allocation of necessary funds is not yet performed, anticipated or provided for the clearly rising threat to urban population health and life due to sharply increasing emissions of particulate matters caused by vehicle operation, in order to eliminate this emerging danger of air pollution in cities and megalopolises caused by the asphalt roadway and tyre wear.

Due to the abovementioned issues of the increasing urban atmosphere pollution, there arises a need to realize the degree of the economic damage to the economy of the states and global economy.

As previously stated, according to the WHO research, within the period up to 2013, about $8 \mathrm{mln}$ people in the world die because of atmospheric pollution with 
carbonaceous particulate matters, as well more than $1.35 \mathrm{mln}$ people die in road accidents, and up to $50 \mathrm{mln}$ people get injuries of various degrees of severity. Plus, taking into account the deaths of people during the ongoing pandemic (COVID-19), which has already killed ca. $5 \mathrm{mln}$ people within the current period, the total fatalities in the developing civilization of the modern global society amount to about $14 \mathrm{mln}$ people already $[8,9,10]$.

Since by the end of 2021, the total Earth population already amounted to about 8 billion people, and in the Russian Federation, the population amounted to about 150 million people, i.e. in total only about $2 \%$ [11].

However, there is some difficulty in estimation of the human life cost in different states for determination of the total amount of economic damage caused by the deaths of people due to the consequences being analysed above. The human life cost (value of statistically average life) is a relative imputed economic value to determine which various methods and parameters are applied. The most objective assessment is performed based on the gross domestic product (GDP) per capita $[9,12,13]$.

Accordingly, the GDP which has not been obtained due to the premature death of a person is the cost of their life. The performed analysis of different legislations showed that the total cost of human life in the world, as enshrined in the regulations, on the whole amounts to 4.7 million US dollars $[9,12,13]$.

Based on the above materials, it is reasonable to assess the damage from the premature death of people caused by different disasters and tragedies per the GDP value in the context of the Russian Federation and the global economy on the whole.

When assessing global damage from the death of $8 \mathrm{mln}$ people, according to the data of the World Health Organization (WHO) for 2013, caused only by atmospheric pollution with particulate matters, if the value of human life outside Russia is $\approx 4.7$ mln US dollars, we get the annual damage to the global economy amounting to about 40 quadrillion $\left(40 \cdot 10^{15}\right)$ US dollars. 
Thus, when assessing by the end of 2021 and taking into account the growth of PM emissions from 2013 to 2021, we obtain the total annual population fatality resulting from man-made and ecological disasters of not $14 \mathrm{mln}$ people but $17.5 \mathrm{mln}$ already due to the growth of PM emissions from the roadway wear from 770 thousand to 950 thousand tons that is by almost $25 \%$, so the annual damage to the global economy already amounts to 81 quadrillion $\left(81 \cdot 10^{15}\right)$ US dollars.

With the population of the Russian Federation of about 150 mln people, we have only about $2 \%$ of the total global population. Thus, the annual damage to the Russian economy can be about 1.6 quadrillion $\left(1.6 \cdot 10^{15}\right)$ US dollars.

Following this arisen global problem, the European Economic Union (EU) countries have coordinated \& agreed upon the European Green Deal project, which is a program of economic reforms aimed at combating climate change and improving the environmental situation. On 14 July 2021, the European Commission accepted a package of proposals aimed at making the environmental, energy, land use, transport and tax policy of the EU suitable for reduction of greenhouse gas emissions by at least $55 \%$ by 2030 compared to the level of 1990 . One of the primary goals is complete decarbonization (zero carbon dioxide $\mathrm{CO}_{2}$ emissions or carbon neutrality) by 2050 [8].

At the moment, the world community is planning a major manufacturing technologies review to decarbonize the global economy. Cutting hydrocarbon energy is the main focus of these reforms. According to the plan, hydrocarbons will be severely combated. Financing of new coal power station construction will be prohibited. Moreover, all subsidies on hydrocarbon fuel will be abolished, while investments in oil and gas production are planned to be limited through international regulations [8].

It is important to note the all around efficiency of vehicle manufacturers' works on fuel consumption reduction by way of example of passenger cars within the period from 1970 to the present day, due to which the fuel consumption has been reduced on average from $12.01 / 100 \mathrm{~km}$ to $5.01 / 100 \mathrm{~km}$, i.e. more than 2 times, which means the greenhouse gas $\left(\mathrm{CO}_{2}\right)$ emissions as well as highly hazardous 
particulate matters emissions have also been significantly reduced. Figure 4 provides the total efficiency of reduction of environmental damage and economic losses in accordance with UN Regulations concerning hazardous substance emissions with EG from passenger cars and trucks [4,5].

Now, it shall be mentioned that the problem of toxicity of particulate matters carrying cancerogenic substances in exhaust gases from vehicle engines and the problem of preventing cancerous diseases among the population of our planet persist already from long ago, for more than 100 years, while no risk reduction can be seen [14].

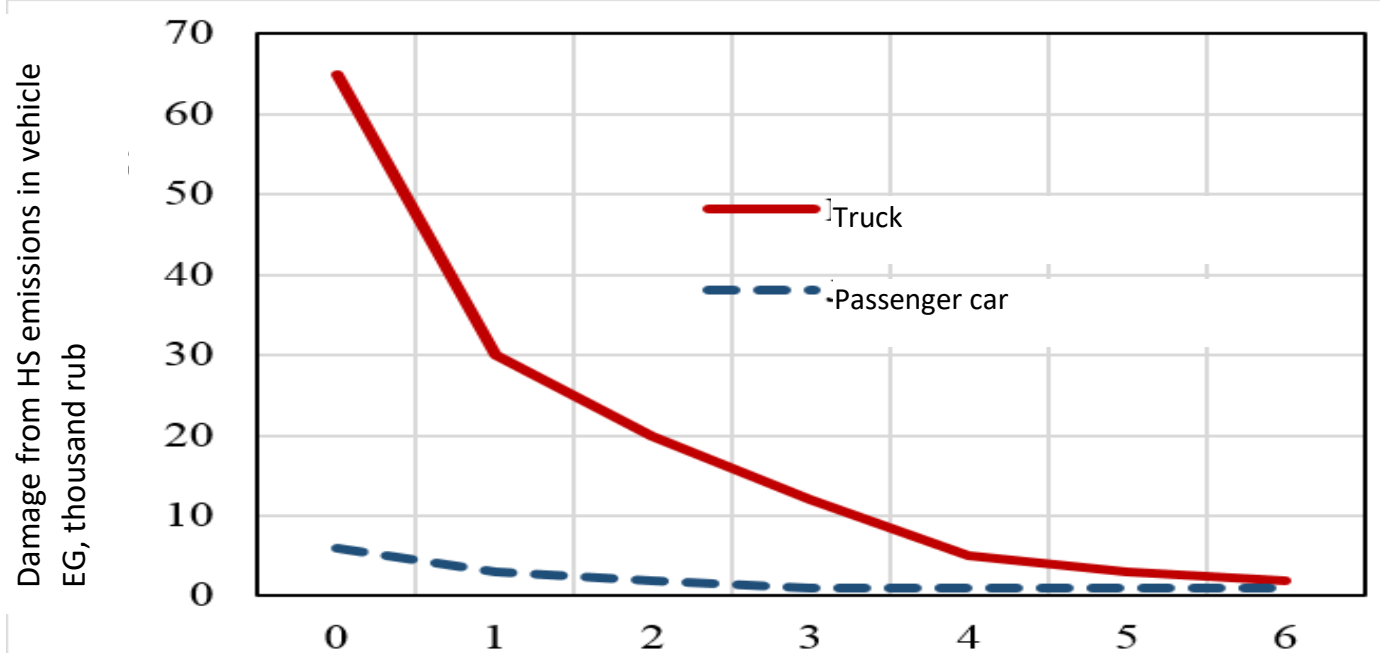

Euro-0 to Euro-6 standards of UN Regulations No. 49 and No. 83.

Fig. 4. Reduction of economic damage from HS and PM emissions in vehicle EG.

This paper is focused on the fact that, from 1925 to 1950, there was a sharp increase in the lung cancer incidence rate in a number of countries (Fig. 5).

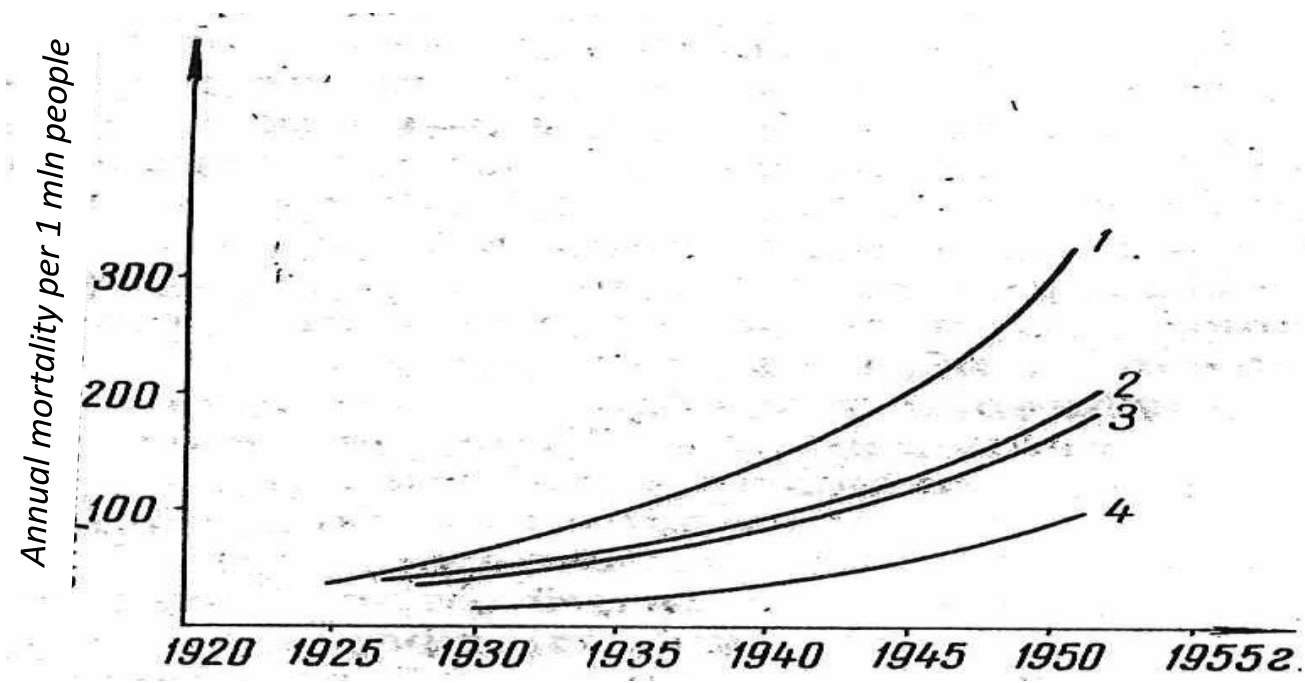

Fig. 5. Increase in mortality caused by lung cancer in different countries 
(according to Doll).

1 - England (Scotland); 2 - the Netherlands (Switzerland); 3 - the USA (Denmark); 4 - Norway.

The fastest growth of the lung cancer incidence rate was in England that was ranked 1st in the world in lung cancer incidence. Thus, during the period from 1900 to 1953 , the lung cancer mortality in England increased by 43 times [14].

An increase in the lung cancer incidence rate can also be seen in the USA, Germany, Austria, Finland, Norway, Denmark, Canada, Australia, India and other countries [14].

In the USSR, the lung cancer mortality increased by three times during this period [15].

With the growth of industry and automotive transport, lung cancer is becoming more and more prominent among other types of malignant tumors. For example,

in 1890, lung cancer was ranked 14th, in 1924 - 9th, in 1930 - 3rd and in $1981-$ 2nd (following gastrointestinal tract tumor) [16].

It should be emphasized that these significant figures refer to the period before the year 1950. Beginning from 1950, the number of vehicles started to double every 10 years. Within the period from 1970, there was a sharp increase in the global vehicle fleet - from $250 \mathrm{mln}$ to 1.2 bln today.

In the 1960s, the issue of atmospheric pollution caused by exhaust gases, which were visible and chemically perceivable at that time, in the cities of developed countries reached critical levels (photos).

Thus, in Los Angeles, California (USA), in 1959, a standard limiting carbon dioxide $\left(\mathrm{CO}_{2}\right)$ and hydrocarbon emissions was adopted, and then, in 1963, a US level standard was approved. 

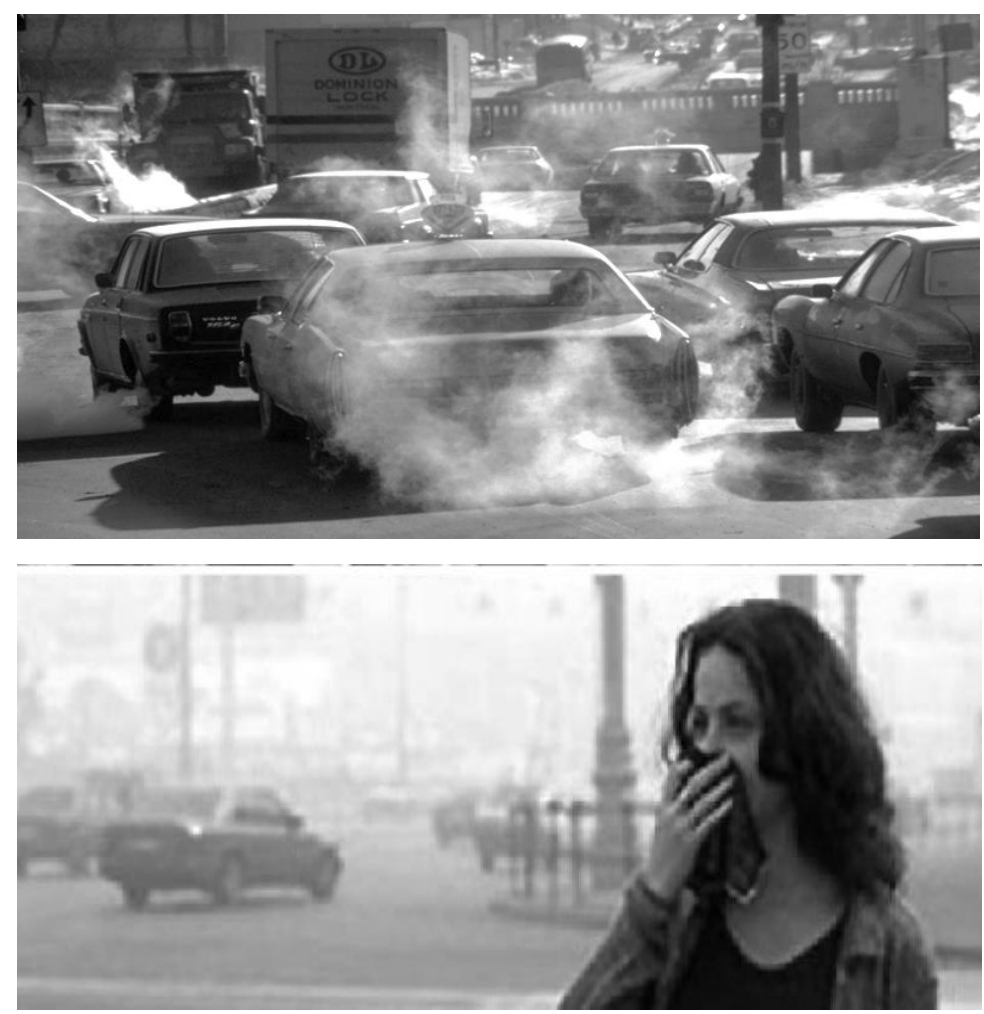

Unlike the USA, the European countries are concentrated on a relatively small territory, so they actually faced the same pollution problem as Los Angeles earlier. In 1952, the Road Transport Sub-Committee (of the Inland Transport Committee) of the United Nations Economic Commission for Europe (UNECE) established the Working Party of Experts on Technical Requirement of Vehicles (WP.29) that started to develop standards containing safety and environmental requirements for vehicles.

During the development of the standards, the USA experience was used, however in 1971 some methods applied in the USA were turned down at the 7th international session of the Working Party on Pollution and Energy GRPE of WP.29 of UNECE ITC, as they were questioned on the basis of the report of the USSR representative based on the results of research on the cancerogenic substances contained in both exhaust and crankcase blow-by gases which, according to the USA suggestion, returned back to the engine without filtration, which resulted in quite high emissions of the cancerogenic substance - benz $(\alpha)$ pilene - from 25 to 200 times $[16,17]$.

Highly important data were provided at further UNECE ITC WP.29 GRPE sessions by European Tyre \& Rubber Manufacturers Association (ETRMA) 
presenting results of PM chemical analysis (Table 1) for the content of various polycyclic aromatic hydrocarbons $(\mathrm{PAH})$ therein that contain cancerogenic substances causing human cancer diseases.

The values are expressed in parts per million ( $\mathrm{ppm}$ ) in the matters mix, sampled behind a moving vehicle.

Table 1

\begin{tabular}{|l|c|c|c|}
\hline Chemical substance & $\begin{array}{c}\text { Road } \\
\text { particles (RP) }\end{array}$ & $\begin{array}{l}\text { Tyre wear } \\
\text { particles } \\
\text { (TWP) }\end{array}$ & $\begin{array}{c}\text { Tyre (tread) } \\
\text { particles (TP) }\end{array}$ \\
\hline Acenaphthene & 4.08 & 0.04 & 0.13 \\
\hline Phenanthrene & 53.4 & 1.66 & 1.21 \\
\hline Pyrene & 54.84 & 4.77 & 0.06 \\
\hline Anthracene & 7.36 & 0.1 & 0.11 \\
\hline Benzanthracene & 38.65 & 0.18 & 2.87 \\
\hline Benz(a)pyrene & 12.51 & 0.28 & N.D. \\
\hline Benzo(k)fluoranthene & 7.4 & 0.02 & 0.92 \\
\hline Chrysene & 17.72 & 0.36 & 2.95 \\
\hline Dibenz(a,h)anthracene & 2.56 & 0.1 & 0.87 \\
\hline Fluoranthene & 82.13 & 0.98 & 1.62 \\
\hline Indeno-1,2,3(c,d)pyrene & 5.36 & 0.21 & N.D. \\
\hline
\end{tabular}

This list contains the PAHs most widely spread in the environment and considered cancerogenic and able to provoke cancerous diseases in people according to the International Agency for Research on Cancer (IARC).

Due to the abovementioned current underestimation related to the dramatically increased PM emissions from tyre wear and, in particular, roadway wear, there is a global ecological paradox between the transport and the environment, especially in big cities, which by the current time period has become critical both by its level and violent growth, exceeding the increase in people's deaths caused by the COVID-19 pandemic by more than 2 times. 
Proceeding from the above facts of the existing invisible air pollution in the human living environment by cancerogenic PM, urgent decisions by the WHO, all the governments and the UN are required for development of certain global activities predetermining real decrease in these hazardous particulate matters emissions caused by the abovementioned emission sources to sharply decrease in the planet population death rate.

Thus, based on the abovementioned, there is a need to promote discussion of the following issues of concern by the national and international legislators:

I. In the current situation, where the urban atmosphere is polluted by hazardous PM, it is necessary for the leading countries' Governments to initiate and sponsor serious research developments related to reduction of the content of substances hazardous to human in materials used for production of tyres and roadway, while the international community needs to develop the respective regulatory requirements.

II. The tyre manufacturers and road construction services shall revise the existing technology for production of tyres and roadway considering the potential of ongoing research and development in terms of new materials and technologies to eliminate cancerogenic substances at their current production.

III. The current situation of the atmosphere pollution, especially in urban areas, where the majority of humanity lives, requires immediate intervention of the United Nations (UN) and the WHO in this problem solution.

\section{References:}

1. World Health Organization, 2014 https://www.who.int/publications/list/2014/ru/

2. https://www.who.int/ru/news-room/detail/02-05-2018-9-out-of-10-peopleworldwide-breathe-polluted-air-but-more-countries-are-taking-action.

3. V.K. Azarov, V.F. Kutenev. On Environmental Hazard of Active Usage of Nonrenewable Resources by Machine-Building and Motor Transport Complexes. "Ecology and Industry of Russia" Journal. - M., 2014. - September. - P. 39-43. 
4. V.K. Azarov. Development of comprehensive procedure for research and assessment of environmental safety of vehicles. Thesis (dissertation) in support of the academic degree of Candidate of Engineering Science (PhD). M.- 2014. P. 135.

5. ECE/TRANS/WP.29 Reports of the Russian Federation over the period from 2013 to 2020 at the sessions of the World Forum for Harmonization of Vehicle Regulations WP-29 of the UNECE ITC on non-exhaust emissions of particulate matters in the atmospheric air of cities, caused by tire and roadway wear.

6. V.K. Azarov, A.V. Vasiliev, V.F. Kutenev, Reasons of Increasing Contamination of Big City Air by Suspended Particulate Matters Resulted from Vehicle Fleet Operation, Ecology and Industry Journal, M., 2017, Vol. 21, No. 8, pp. 44-48.

7. V.F. Kutenev, A.M. Saykin, V.K. Azarov, Problems of Creation of Ecologically Clean Vehicle. Avtomobil'naya promyshlennost', 2013, no. 10, pp. 5-7.

8. Energy Policy. Public Business Science Magazine, No. 7 (161), 2021.

9. https://www.who.int/violence_injury_safety_status/report/ru/

10. https://www.google.com/search

11. https://countrymeters.info/ru/World

12. A.N. Zubets, A.V. Novikov Quantitative Assessment of the Value of Human Life in Russia and in the World. Finance: Theory and Practice/FINANCE AND PRACTICE. Vol. 22, No. 4'2018.

13. https://imemo.ru/files/File/magazines/Osn_pokaz_ME/2020/FullText2020.pdf Givi Machavariani, World Economy Forecasting, IMEMO.

14. Doll R. Etiology of lung cancer. In book: "Advances in cancer research", v. 3, P. 1-50, 1955.

15. L.M. Shabad, A.Ya. Hesina, Cancerogenic Hydrocarbons in Exhaust Gases of Vehicle Engines and Problem of Cancer Prevention. FEDERAL SCIENTIFIC RESEARCH DESIGN AND TECHNOLOGICAL INSTITUTE OF ENGINES, Moscow, 1981, P. 43-60. 
16. I.L. Varshavsky, B.N. Dotsenko, V.B. Klyatskin, V.F. Kutenev, E.P. Mosikhin, A. Ya. Hesina, S.S. Khitrova, L.M. Shabad, Dependence of Values of Toxic Substances Emissions by Positive Ignition Internal Combustion Engine on the Method of Crankcase Gases Disposal, Reports of the Academy of Sciences of the USSR, 1970, Vol. 196, No. 3, pp. 654-657.

17. V.F. Kutenev, V.N. Topunov, A.A. Charykov, Crankcase Gases and Emission of Toxic Substances with Vehicle Exhaust Gases // Reports of the 2nd Symposium of the CMEA and SFRY member states, 1971, p. 104-110. 